\title{
INSTITUTIONAL LAND PASSES MASTERY INHERITANCE PATTERN, ON A FARM IN THE HIGHLANDS OF INDONESIA
}

\author{
Nurdin Mappa (a) Darmawan Salman (b) Ahmad Ramadhan Siregar (b) Muhammad Arsyad (c) \\ a) University of Muhammadiyah Makassar \\ b) University of Hasanuddin Makassar
}

\begin{abstract}
The community of farmers in land tenure have different institutional in terms of mastery of the land. In Indonesia there were generally institutional governing the utilization of land for mastery permanently, but there were also institutional governing dominion land in turn. This research aimed to chart institutional pattern characteristic mastery of the land inheritance system passes in, andanalyzeits contribution to sustainability of agriculture in the economic, social and ecological. Research method using case studies, with unit case a subdistrict in Gowa, South Sulawesi province, Indonesia. The results showed that institutional land pattern mastery system passes the inheritance patterns of alternation that has in effect hereditary, pattern rotation established by the heir land management patterns, depending on the number of beneficiaries, as well as not having managed to land fragmentation, so the scale of farming land, conditions can be maintained, the land was slanted so given a terracing, planting process was carried out by means of mutual. Neither found that institutional land pattern mastery system passes the inheritance had been contributing the sustainability of agriculture in social and ecological, but have yet to fully contribute to the sustainability of agriculture in economy.
\end{abstract}

Keywords: institutional, land, alternate, mastery and sustainable

\section{Introduction}

Land in agricultural business management is one of the means that was very important, both in the past, now and in the future (Ramos Ribeiro, Madeira, Menezes, \& Correia, 2013; Koirala, Krishna, Mishra, \& Mohanty, 2017; Rao, Spoor, Ma \&,2016; Pritchard, 2016). Therefore the mastery of the land much needed by farmers to manage their farm businesses in the long span of time (Rao, et al., 2016), especially mastery of land by local people based on wisdom and traditional systems that they run in order for the sustainability of agriculture (Irmayani, et al, 2016; Susilowati \& Maulana, 2012). Mastery of land land in private had increased in the form of ownership, rental, and the right is not clear (Ege, 2017), but also of imaginary land ownership by the Government and the State (Hausner, Brown \& Lægreid, 2015). Meanwhile mastery of land ownership in the form of custom is very diverse, complex and dynamic (Lambrecht, \& Asare, 2016). Therefore required more attention on local political dynamics on the reform of ownership to increasingly give way to the contribution of non-State 
institutions such as the Institute of indigenous or other local institutions in the dominion land (Leeuwen Monday, 2014). In the Philippines there have been laws protect ownership against the rights of indigenous peoples over their ancestral lands and territories, though its implementation has not been fullest (Drbohlav \& Hejkrlik, 2017), while in many places the land ownership has been give rise to a variety of conflicts (Ryder \& Hall, 2017, rich, \& Erol, 2017; Ianoş, Sorensen, \& Merciu, 2017). One of the reasons of occurrence of conflicts due to the takeover of ownership by means of eviction and the intervention of the Government (Peter Ho, 2014), there's even a customary leaders who sell agricultural land and land that has not been one to a stranger, for the purpose of residence, which caused the conflict and change the traditional livelihoods, plus the results of the sale are not enjoyed by the beneficiary, as well as those driven out of their lands by force (Peter Ho, 2014).

Mastery of the land in some countries has taken place the evolution from communal to private parties in private due to the presence of migirasi inhabitants in the villages, even personal ownership tends to be higher (Mwesigye; Matsumoto, Otsuka \&,2017; Basupi, Quinn \& Dougill, 2017), while in many countries, land use has been going on land conversion from farmland to non agriculture, which resulted in the increasing residential land, otherwise dwindling farmland (Spalding, 2017; Mmbaga, Munishi, Treydte, Hanhm, in Iran, Ton \& Lebailly, 2017; Miheretu \& Yimer, 2017; Jin, Nasiri, Han Li, \& 2014). For example, the land area that is managed by farmers in Cambodia found very small and $55 \%$ of the land has been managed left (Nakalembe, Dempewolf, \& Justice, 2017). Similarly, the fragmentation of agricultural land into farm-land is more sempitjuga much happening in some countries such as in Romania and other countries including in Indonesia (Susanti, Hidayat \& Sukesi, 2013; MAG-Petrescu, 2017; Li, Rodriguez \& Tang, 2017), depreciation has occurred even in total land used for cultivation in Yubei District Chongqin result of increasing population and economic development, because the conversion rate of agricultural population (Zheng \& Ran, 2012) but the awareness to preserve the land by not doing the sales have started to grow, especially in Malaysia (Hamza at al, 2013).

In general the mastery of land petanian in Indonesia particularly Java, especially villagers have its own system in land ownership, one of the system of individual ownership belonged to hereditary originating from land inheritance, the system of land ownership and communal discovery, own land, land rental and sakap of others (Gunawan1984, Sudrajat, 2014), while in the Southeast Sulawesi, Buton discovered the existence of the institutional system of land ownership-based tradisilokal named parabela. Parabela local leadership figures with regard to the rules of the game and in the management of agriculture in General and land ownership (La Nalefo, et al, 2013).

Mastery of the land in the area of Highland Subdistrict Tombolo Pao had Characteristics its own compared to the mastery of land elsewhere, namely land pattern mastery passes obtained through inheritance system, the system of purchase rights the management of the system of ownership of the pipeline system and the sharing of the land purchase. This research focused on the mastery of the institutional system for the inheritance cycle through patterns of land use, which aimed to describe the institutional charateristics mastery of the land passes inheritance patterns and institutional relations to 
analysed mastery of the land passes inheritance pattern with agricultural sustainability in social, ecological and economic issues.

\section{Research methodology}

This research method applied case studies, with unit case a subdistrict in Gowa, South Sulawesi province, Indonesia. The focus of the case was a proper land management cycle through patterns of heredity.

Data collection was done through in-depth interviews with farmers land owners, farmers, government workers villages, land deed official agricultural extension officers, and local figures. Data was collected through observation to the existence and the process of land use physically. The data obtained are then classified based on needs in the form of a matrix, then analyzed by means of describing institutional characteristics mastery of the land system is a legacy in terms of the pattern and structure alternation mastery of the land inheritance system passes, the parties involved in the management of land, heritage land rotation conditions, the rule of the game, the process of land use, as well as the institutional relationship mastery of land inheritance system passes by agricultural sustainability in social, ecological and economic issues.

\section{The Result}

\subsection{Condition of land mastery}

Tombolopao Subdistrict Land Condition is one of the subdistricts Gowa regency, South Sulawesi province, Indonesia. Gowa Regency has an area of $251.82 \mathrm{~km}^{2}$, while used as agricultural land is an area of 4,996 ha, which was divided into rice fields land 4,296 ha and 700 ha of land for fields (BPS Kabupaten Gowa, 2016). Plants that were cultivated are rice crops, crops and horticulture, with average mastery of land perpetani 10.5 -acre ( $0.1 \mathrm{ha})$.

Mastery of the land in district Tombolopao consists of two forms namely mastery of land on a permanent basis and the control of land traditionally passes. Mastery of land regularly was owned by individuals and in the management carried out continuously without any management turnover every year. Mastery of the land in turn was mastery of land owned jointly (communal) that the operations conducted in turn every year or even more than a year, depending on how many members of the community who manage in turn, thus passes a year, the two Governments three years and beyond. Mastery of the land passes in district Tombolopao found four system, namely land pattern mastery system passes by inheritance, land ownership system rotation form mastery of the pipeline, land pattern mastery system passes the purchase rights land and system passes the sharing of land purchase.

Mastery of the land inheritance system passes pattern comes from land inherited by an heir to the beneficiary, who in the operations conducted in turn among the heirs. Farmers who apply the patterns of alternation through inheritance there are about 43.6 percent of the total community and land of about 53.8 percent of the total land. 
Land pattern mastery system passes the purchase of rights to land is the mastery of the land obtained by way of buying land rights to members of the community, which has rights to be rotated. Buyer or owner rights to replace the then land, occupying the land in turn by other community members, who still holds the rights to his reign. Farmers who had the rights to the pattern of passes by purchasing land rights there are about 33.3 percent, with land of about 26.2 percent of all existing paddy fields in district Tombolopao.

Mastery of the land ownership system passes the pipeline pattern, was the mastery of the land against a land traditionally passes between two or more persons, due to the existence of a partnership between landlord and tenants in did a land with the deal, after the completion of land under cultivation, they unanimously agreed that do land in mastery of the passes. Farmers involved in the mastery of the land ownership pattern, the system passes the pipeline there are about 10.3 per cent, with an area of land that was occupied about 6.7 percent of its land area.

Land pattern mastery system passes the sharing of land purchase, was the mastery of the land pattern passes caused by the purchase of a land between two or more persons, by way of a share. The land was later purchased privately run passes. Farmers involved in the management system of the sharing of land purchase have around 12.8 percent of the land area controlled by 13.3 percent.

\subsection{Institutional Karesteristik mastery of the Land Inheritance System.}

Passes the mastery of Patterns of land inheritance system passes patterns were derived from land owned by grandparents who originally has not been rotated. After the land handed down to second generation i.e. father or mother, the mastery of the land has begun to be rotated among the brothers. Pattern Mastery set Grandma or coordinated among the fathers or mothers brothers. The rule of the game that already agreed applied continuously until the grandchildren and great-grandchildren. If the father or mother of the brothers just two people, the pattern is cycles a year it means one year managed by children first, one year maintained by the second child. If the three brothers then pattern mastery into three-year cycle means that the first year was administered by children first, second year maintained by the second and third year administered by the third child. If the father or mother dies land rights handed down to grandchildren, then among the grandchildren occured severally with mastery of the land are following a pattern applicable to the father or mother, then cycle through patterns of land-derived mastery on the tweet. The legacy managed to land passes are not shared, so the land did not experience increased, however, fragmentation is the Manager of the land.

One of the facts of the case the mastery of the land inheritance system passes, the patterns found by the researchers was a case of 35-year-old, Arsyad, resides in the village of Bolaaromang. Managed land passes were in the village Bolaaromang, village Bolaaromang, 3 acres (0.03 ha). Land that borders the land passes managed by Baco on sebelahUtara, Rabali on the South, while to the West it borders land controlled by Rappe and the East borders on land controlled by the Pawa '. Managed land passes come from Grandma, named Da'to who bequeathed land and land management to his two sons, called Pu'do 
and Ja'pa in 1977, in that was starting to happen to land management patterns of inheritance cycle through the system. Employee administration passes at the start by Pu'do in 1977 and then in 1978 was managed by Ja'pa. This pattern continued to apply until the year 2007. In 2007 Pu'do was later bequeathed to his son (grandson of Da'to) named Jalil, Saturday, Sawiah and Jawiah, while Ja'pa inherited rights management in the year 2008 to the fourth son (grandson of Da'to), who was named Arsyad, the judge, pure, and Hashim. The management of first-year, i.e. the year 2007 conducted by Jalil Pu'do, a derivative of the following year, i.e. the year 2008 was administered by Arsyad, the derivative of Ja'pa. Third year i.e. 2009 year are managed by Saturday, Pu'do derivatives, i.e. year 2010 fourth year managed by judges, a derivative of Ja'pa, i.e. the year fifth year 2011 managed olehSabtu, Pu'do derivatives, sixth year 2012 year that was managed by the pure, the derivative Ja'pa, seventh year i.e. year 2013 was managed by Jawiah, a derivative of the Pu'do and eighth year managed by Hasni derivative Ja'pa, until the eighth year of a crop cycle was completed, then back again started a new cycle, the rule of system was valid until to tweet and not affected by gender. Land pattern Penguasan passes on the case land pattern mastery Arsyad passes born of grandmother's legacy, the rule of the system applicable set by heir (grandmother) started from the first-born child, until the most youngest. The provisions of this agreement that cannot be modified by anyone, so the rule of the system will be valid till great grandchild

In case of land use pattern mastery Arsyad passes on the child was one year as of partner that was managed by the descendants of Pu'do, a one-year run by the descendants of Ja'pa. This pattern remained in effect after the land run by the grandson of Da'to i.e. generation Arsyad along his cousins, and so formed the structure pattern mastery system land inheritance passes as in Figure-1.

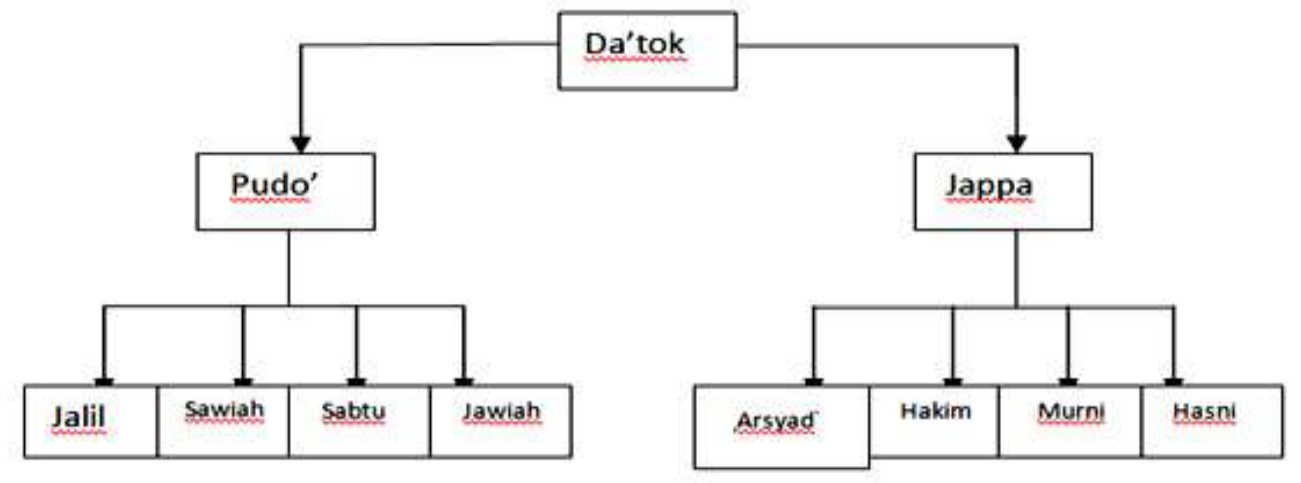

Figure-1. The Structure Of The Pattern Of Land Use Pattern Mastery System Passes The Legacy

The structure pattern of the mastery of land described the origins of rotated land, and anyone involved in alternation at once describing how many involved in land management in turn.

Implications in the institutional patterns of land possession system passes the inheritance had given rise to an institutional land pattern mastery passes, which was characterized by the existence of a rule of the 
game that set a pattern of alternation of mastery of appropriate land with the number of heirs, neither the process of rotation has been set, the start of the oldest brother to sibling most youngest. While the implications of social, institutional land pattern mastery system passes the inheritance has been transformed into a container to bring together and reconciling family relationships so that the rotated commonly known by the term ground sibling, meaning farm family, because anyone who had land rights on land that rotated can be assured they are family relationships, though the family had been away and was no longer known. Institutional land pattern mastery system passes a legacy, also implies scale farmer can be maintained, therefore having no land fragmentation, land was not divided by the heirs, but the number of the Organizer more increased diversion occurs every rights management to the next generation. Mastery of land inheritance system passes pattern also implies cooperation in farm practices plant, where community members who have land rights to join the Brewers share the work in suitable planting. The inheritance pattern has recognized gender equality in land rights, therefore all heirs are entitled to rights to land without discriminating between men and women.

\subsection{The conditions and land utilization that in turned.}

Generally managed land passes in Tombolo Pao, had a somewhat tofografi slant with slopes between 250-350, the conditions of land was generally narrow and elongated follows the State of tofografik of land, it was because of being in the slopes of the mountain, so that his land terracing. The color of the soil of almost the same that was browned. Wetland conditions in General watering except during the dry season.

In the case of land in turned of Arsyad, covering an area of $300 \mathrm{~m} 2$ are on land that was somewhat slanted so that it can calculate the terracing that were restricted by the small dykes, elongated-shaped land with soils were browned. Manufacture of teracing on the land was a smart tactical steps from a farmer for land conservation on sloping land, primarily to maintain the fertility of the land, prevent the occurrence of topsoil removal which is rich in the flowers of the soil or topsoil, prevent the occurrence of landslides as well as to accommodate water flowing directly from the surface.

In general the process of land used that in turned of starting from processing of land used tractors or proprietary lease, even still exist that used the energy animals to plowing. The next process of land planted with mutual way, performed by giving the plant maintenance and keep the water which comes from irrigation and weeding out and give the fertilizer that most use chemical fertilizer, process next is energy harvesting using mercenaries.

In the case of land privately Arsyad passes was located in the hamlet of Bolaaromang, village of Bolaaromang sub-district of Tombolopao. Land management was done on the planting season, about the month of January to June, the plants grown was rice plant type of premises, which was about 6 months. The energy involved in the processing of land ranging from piracy to planting one person, with the average cost of processing land as much as $\mathrm{Rp} 300.000$, whereas at the time of planting rice 
seeds carried by way of mutual family power by involving about 20 people, all personnel involved mutual work no one earned. Planted as many as 8 litre priced at $\operatorname{Rp~48,000.~Maintenance~of~the~plants~}$ still used chemical fertilizers subsidized as much as one zak at IDR 125,000. The energy used in the maintenance of family power was as much as one person. Crop harvesting was done at the age of six months. Power came from the ranks of the family but they get their wages, granting wage system was with the system for the results i.e. 10 belt out a bunch. Yields are obtained as many as 15, if converted into rice around 150 litres, with a price of around Usd 7,000, yields obtained IDR 1,184,000. Postharvest handling by means of binding of rice in one bond was called a rope, then yields under the House, the first harvest considered superior to IE that has the ear of many and large prepared into the seeds, then placed in top of the attic of the House.

\subsection{Relationship between institution mastery of the Land passes with Agricultural Sustainability In} social, economic and Ecological.

The relationship between institutional land passes mastery with agricultural sustainability in social, can be seen with this form of cooperation, which is done by the farmers who have the right management of passes. This form of cooperation is mutual work. The activities of the mutual work appears at a time when land Manager passes, do the planting rice seeds, plant on land that they work on. Other farmers called volunteer (nipakionkangi) to get help without wages, they just treated to food and drink after coming home to work, this mutual activities can also be seen in the activities of the maintenance and repair of irrigation by farmer called water retainer mutual activity of cleaning and repairing irrigation canals was done ahead of the planting season. Conflicts often occured only with regards to time alternation, where sometimes there are community members who would like to manage, but not yet the turn time. Conflict resolution is usually resolved by way of amicable, in consultation between the two parties in conflict, bela is facilitated by mataere retainer.

In the case of Arsyad, the activities in the form of mutual cooperation, held on the activities of the cultivation of the plant. Mutual was conducted one time in one growing season, so in one year done two times, farmers who shared the work around the 20 people, all of which were communal, which had involved in land management pattern of passes or close family. Mutual process starting from the notification time of planting to the family, later in the day, they came to land simultaneously performs the same together-planting to completion, the process of planting was complete in time a day. As a form of reply from the owner of the rights to land pattern passes, they prepare the need, in the form of konsunsi and drinks after returning home, and share a mutual help other farmers in times of needing.

In the case of conflict between the land Manager Arsyad passes had never happened. However, Arsyad as joint retainer water (water springs) village authorities, often reconcile conflicts because of the scramble for land management rights. The fact that often occured is the party that claims the Manager was running, so the scramble for schedule management, step a settlement arranged by retainer 
mataere (water springs), by asking the origin of the family, if the family is already known clumps that claim, then it can easily be demonstrated when time management for clumps, so that the conflict can be minimized with ease, because the party claimed receptive after the indicated time management for clumps that claims

This condition indicated that the sustainability of agriculture is socially, which is indicated by the existence of cooperation and conflict resolution are met, so that it can be meant, that the institutional management of passes, ensuring sustainability of legacy systems Agriculture is socially.

While actions taken by farmers, associated with ecological preservation of them, was not the plant functioned as the rice fields of various types of trees, neither to keep land that is managed, are not subjected to landslides, easy hold water, then on paddy fields, terracing or made into senkedan land, as well as serve as dykes or limit between the rice fields.

In the case of environmental preservation conducted, Arsyad way plant plants surrounding paddy fields, which are located at village Bolaaromang. Planting had been operating, committed by parents until now, and stay awake by their grandchildren, neither to keep the land can be awake, especially of the avalanche then paddy fields that exist in the hamlet of Bolaaromang village Bolaaromang, created, terraced with how to make terracing. The making of terracing land created since printed into the rice fields by heir i.e. land lord first. Tree planting was intended to be able to stand the erosion, and store water, so as not to cause floods, intended to facilitate the implementation of the terrace land of arable land and expand as well as to accommodate more water on land.

Arsyad pointed out, that the institutional management of land inheritance system passes, has contributed to the sustainability of agricultural ecology, but there was still one indication has not been met, i.e. organic farming practices have not been applied completely, but to keep the land in physical in order to remain sustainable as it was not a landslide, not subjected to annihilation by the water, and the soil can hold water, it had been done with the how to make a terracing (patio or sengkedan) on land. In general the work of residents in Tombolopao is farming, so the field of farming the most absorbing labor was agriculture. In the case of farming analysis results found Arsyad that $\mathrm{B} / \mathrm{C}$ ratio of 0.4 and a $\mathrm{R} / \mathrm{C}$ ratio of 1.3 . Based on the calculation of the $\mathrm{B} / \mathrm{C}$ ratio and $\mathrm{R} / \mathrm{C}$ ratio in the case of Arsyad pointed out that institutional land inheritance system passes mastery, economically yet bring benefits if seen from the $\mathrm{B} / \mathrm{C}$ ratio, because the results of the analysis $\mathrm{B} / \mathrm{C}$ ratio is still less than 1 that is 0.3 whereas analysis using $\mathrm{R} / \mathrm{C}$ ratio result greater than 1 that was still considered so auspicious 1.3 , can therefore be drawn the conclusion that the institutional land management patterns turn the system legacy has not been fully contribute to the sustainability of agriculture in the economy.

\section{Discussion .}

The Institutional management of land traditionally passes the system legacy in district Tombolopao, born from the idea of society as a form of solution from the limitations of the available land, while many 
arable land, requiring therefore a growing population, agricultural land tends to stagnate, while a growing number of residents who are in need for farmland. It is similar to what is called by Geertz (1983) involution of farming land that is likely to stagnate however tenants are increasingly growing. On the sustainability of agricultural land management patterns traditionally passes on legacy systems, has narrowed the occurrence of land fragmentation, this contrasts with the results of some of the researchers who discovered the use of land conversion from land Agriculture to non agriculture, which resulted in the increasing settlement of land otherwise dwindling farmland (Spalding, 2017; Mmbaga, et al2017; Hanhm, et al, 2017; Miheretu \& Yimer, 2017; Jin, et al, 2014), including in China has been going on land conversion quickly caused by acceleration industrialitation and urbanization, even the takeover of land in remote areas was carried out by means of force by the Government with financial compensation low (Hu \& Ran, 2012), even the land area which was managed by farmers in Cambodia found very small and $55 \%$ of the land had been managed left (Nakalembe, et al, 2017). Similarly, the fragmentation of agricultural land into farm-land that was narrower, too much going on in some countries such as in Romania and other countries including in Indonesia (Susanti, et al, 2013; MAG-Petrescu, et al, 2017; Liet al, 2017), even including the Piliphina ownership of indigenous peoples over their ancestral lands and territories being hindered due to the application of the legislation was not to be applied and at the same time separating in the tribe and conflicting interest among members of the clan and used by the company to further enhance their business interests (Hejkrlik and Drbohlav, 2017).

Institutional land management in legacy system passes, had been orally and do not experience a change, even the appropriate fixed and survive, it is different with institutional discovered by Jonah, Salman, Demmallino and Viantika (2016) which found institutional changes, in rice farming in Indonesia post green revolution. Institutional land pattern mastery system passes a legacy, has spawned a community of mastery of the land are not fixed, i.e., the land passed to the sons of descent, who later managed the way passes every year, the land was not owned personal, but rather were owned communally, this discovery was similar to the mastery of the land that was found in Southeastern Sulawesi, Buton (Indonesia), namely the existence of the institutional system of land ownership-based local tradition named parabela. Parabela regard to the character of the local leadership and the rules of the system, in the management of agriculture in General and land ownership (La Nalefo, et al, 2013), but mastery of the land pattern of inheritance system passes, in contrast to what was expressed by Suradisastra and Eunuch (1992), who in his researched find the existence of a case of Enrekang Regency heritage land, South Sulawesi (Indonesia) which is divided into two parts, one part is inherited and is rendered permanently by the heirs, and one part is done in turn by his heir, known as the land of ongko.

Institutional land inheritance system passes mastery is one of the containers to keep family relationships among land managers, because all involved in land management still families or still the grouping so that in turned to known as (family clumps of land).It was very different, that was reported by Winarso (2012) that broke inheritance system, has led to increasingly narrow land from one generation-ot next genaration, because it tends to sell their land for farmers, since the revenue generated 
does not meet the needs of the living. Winarso (2012) showed, that the legacy of land tenure tend to no longer have a relationship with the other families, so it is no longer the relevance of one family with another family in managing land. Family relationships were still guaranteed, through institutional land mastery in turn, finally can also maintain cooperation in the form of mutual, even conflicts that often arise in mastery of the land, can be stopped through the ways as a family, with deliberation, consensus thing in very different to what is conveyed by the (Ryder \& Hall, 2017, rich \& Erol, 2017, 2017 Ianoş, et al), that in many places land ownership has led to a wide range of conflicts.

Institutional land pattern mastery system passes a legacy, relation to agricultural sustainability in social, with indications presented by Behnasi, Draggang and Yaya (2011) i.e. cooperation and conflict resulusi, has long been applied on institutional land pattern mastery system passes the legacy, namely in the form of mutual work in managing the land, for example at the time of planting, they help each other to work voluntarily, and done in turns, the working practices of Indonesia Brewers were also found, as they do the repair or cleaning of irrigation which is known by the term a'mataere, the activity was performed each ahead of the planting season three times. An indication of the sustainability of agriculture in the other, namely social conflict resolution in land management, completed by way of deliberation by Retainer Mataere, even conflict hardly found. This condition was indicated, that institutional land management pattern of passes in support of agricultural sustainability in social.

On the institutional side of ecology, land management pattern of passes are assumed to contribute with the sustainability of agriculture, as hinted by Behnasi, et al. (2011), because the farmers had conducted land conservation, especially in order to land can withstand the avalanche, land can hold water and land surface removal does not occur, by the water surface, have made the technique of terrace. Land-land that is not used for land pesawahan, had been planted with various types of trees in order to environmental conservation.

Institutional relationship mastery of land inheritance system passes pattern with sustainable agriculture economically, based on production, reception, and income as well as employment opportunities (2011 Behnassi, et al). Based on the results of the analysis of farming with indicator B/C ratio and $\mathrm{R} / \mathrm{C}$ ratio, have yet to fully support the sustainability of agriculture economically, because the $\mathrm{B} / \mathrm{C}$ ratio obtained value is still smaller than the one that is 0.3 , which means farming is on the case Arsyad has yet to benefit economically, but $\mathrm{R} / \mathrm{C}$ ratio obtained greater value than one that is 1.4 , which means farmer in the case of Arsyad profitable. Whereas the indication of the sustainability of the agricultural-based opportunities, such as work, as an indicator of the sustainability of agriculture expressed by Behnassi, et al (2011) are met with either, because in the case of land management cycle through the system of inheritance involves the family in managing a clump of land, so that the land is managed in turn absorb much manpower.

The analysis is based on the economic scale showed, that institutional land management patterns of inheritance system passes, not yet fully contributed with economically sustainable agriculture, but the land management system legacy until now still can survive even the derivative continued up to the last, 
this is due to the image, that if not plant rice they won't eat again, because rice is the staple them, in every family there was always a rice stored in the attic above them. Other causes of the existence of a diversification effort, it is similar with the delivered by Tuyen, (2012) that in order to survive, farmers rich, medium and poor, as well as those without land, must diversify livelihoods, through a combination of activities on the farm, outside of agriculture and non-agriculture, therefore Besides planting rice they also last ZAA farming and supported by social and ecological sustainability.

\section{Conclusion}

Characteristics of institutional land pattern mastery system passes the inheritance can be concluded, that pattern of turned in established by the heir or the result of deliberation between the beneficiary, the pattern of alternation was determined based on the number of beneficiaries, if only two siblings then the pattern was bali a year (cycle of one year), if three brothers pattern bali tallu taun ( 3 year cycle) and so on. The pattern of the management applied orally until the final derivative and may not be modified by anyone. Tofogarafi land was somewhat slanted so that it can calculate the terrace, in the process of land still applied mutual work especially at the time of planting, but harvesting using a system of wages, post-harvest processing by tying rice in one basse (one bunch) then disampan on top of the attic of the House. .

Institutional land pattern mastery system passes the heritage contribute with a socially sustainable agriculture, because in the processing of land still exists in the form of mutual cooperation, and the existence of conflict resolution by retainer apparatus and mataere villages. Institutional land pattern mastery system passes a legacy, also contributed against the sustainability of the agricultural ecology, environmental conservation had been carried out, by means of plant land that is not utilized as rice fields, with different types of trees and making the terrace in paddy fields, to prevent the occurrence of the damage and improve the condition of the paddy fields, but have yet to fully contribute to the sustainability of agricultural-based due to the results of the analysis of farming with the economy of scale, not yet fulfilled.

\section{References}

Agyei, A.P, D. J. Andrew, Lindsay, C.S.( 2015). Impacts of land tenure arrangements on the adaptive capacity of marginalized groups: The case of Ghana's Ejura Sekyedumase and Bongo districts.LandUsePolicy, Volume 49.

Basupi V. L., Q. H., Claire \& Dougill J. A (2017). Using participatory mapping and a participatory geographic information system in pastoral land use investigation: Impacts of rangeland policy in Botswana.Land Use Policy, Volume 64, May 2017, Pages 363-373 
Behnasi M., D. Sidney, \& Sanni Y. (2011). Global Food Insencurity, Rethinking Agriculture and Rural Development Pradigm and Policy. Springer Dordrecht New York Heidelberg London.

Chiaravalloti, M. R, H.Katherine, \&Kirsten E. (2017). Sustainability and Landtenure: Whoowns the floodplain in the Pantanal, Brazil? Land Use Policy, Volume 64.

Drbohlav, P \&Hejkrlik, J. (2017) .Indigenous Peoples' Struggle for Secure Land Tenure in the Philippines: Case Study of Higaonon Tribe in Opol, Mindanao, Asian Social Science; Vol. 13, No. 7, Published by Canadian Center of Science and Education.

Ege S. (2017). Landtenure insecurity in post-certification Amhara, Ethiopia. Land Use Policy, Volume 64.

Fao, 2002. Land Tanure And Rural Deplovment.Food And Agriculture Organization Of The UnitedNations.

Geertz C. (1983). Involusi Pertanian, Proses Perubahan Ekologi di Indonesia, Hasil terjemahan toleh, Supomo, S . Bharatara Karya Aksara-Jakarta

Gittinger, J.P. (1986). Analisa Ekonomi Proyek-Proyek Pertanian. Terjemahan. Edisi Kedua. UI-Press dan John Hopkins, Jakarta.

GrayC., S. Payaman, K. Lien, P.F.L. Maspaitella,\&Varley R.C.G. (1992). Pengantar Evaluasi Proyek. Edisi Kedua. Penerbit Gramedia, Jakarta.

Hamzah , J; Aliasak, Haffiz, M.H, Habibah, A; Buang, A; Hussain, M.Y dan Sivapalan, ( 2013). Development Process and Its Implication on the Native LandOwnership,Asian Social Science; Vol. 9, No. 14; Published by Canadian Center of Science and Education.

Hanhm Q. H. , H. Azadi, Ton, T.D. Vu andPhilippe L. (2017). Dynamics of Agrarian Systems and Land Use Change in North Vietnam, Land Degradation \& Development. Land Use Policy Volume 28.

Hausner H. V, L.G Brown, \&Eiliv, (2015). Effects of landtenure and protected areas on ecosystem services and land use preferences in Norway. Land Use Policy, Volume 49.

Hery, S.S\& Mohamad M. (2012). Luas Lahan Usahatani Dan Kesejahteraan Petani : Eksistensi Petani Gurem Dan Urgensi Kebijakan Reforma Agraria, Journal Analisis Kebijakan Pertanian. Volume 10 No. 1.

HoP. ( 2014). The 'credibility thesis' and its application to property rights: (In)Secure landtenure, conflict and social welfare in China, Land Use Policy, Volume 4.

Ho $P$, (2014). The 'credibility thesis' and its application to property rights: (In)Secure land tenure, conflict and social welfare in China. Land Use Policy, Volume 40.

Hu, X \&Ran, R. (2012). Overview of Multiple Calculating Methods for Land ExpropriationCompensation Standard --- A Case of Arable Land in Nanyang, HenanProvince, China. Asian Social Science, Vol. 8, No. 4.

Ianoş I., A. Sorensen, \& Cristina M. (2017), Incoherence of urban planning policy in Bucharest: Its potential for land use conflict, Land Use Policy, Volume 60. 
Irmayani, D. Salman, D. Rukmana, \&F. Nurland, (2016). Exixtence of Society Rural Community Based Local Resource in Enrekang District, Indonesia. Man In India, Vol. 96, No. 11.

JingL., R. Daniel,\&Tang X, (2017). Effects of land lease policy on changes in land use, mechanization and agricultural pollution Original research articleLand Use Policy, Volume 64.

KayaA. İ. \&KayaN. (2017). Conflicts over Locally Unwanted Land Uses (LULUs): Reasons and solutions for case studies in Izmir (Turkey)Original.Land Use Policy, Volume 58

Koirala K.H., A. Mishra, \&Samarendu M. (2017). Impact of landownership on productivity and efficiency of rice farmers: The case of the Philippines. Land Use Policy, Volume 50.

La Nalefo, M.K. Yusoff, M.S.S. Ali, D. Salman, E.B. Demmallino, Meisanti, Muhidin, I.Y. Ismail, M. Kamaluddin \& Nirwati, (2013). Towards an Institutional Sustainable Agriculture in Parabela. World Applied Sciences Journal, Vol. 26.

LambrechtI., \&Sarah A. (2016). The complexity of local tenure systems: A smallholders' perspective on tenure in Ghana. Land Use Policy, Volume 58,

Leeuwen, v. M, (2014). Renegotiating customary tenure reform - Land governance reform and tenure security in UgandaLLand Use Policy, Volume 39.

MagPetrescu, R. M, D.C Petrescu\& Ioan, V. M, (2017). Whereto land fragmentation-land grabbing in Romania? The place of negotiation in reaching win-win community-based solutions. Land Use Policy, Volume 64.

Miheretu, Asmame, Y. Birhanand, Abegaz, \& Assefa, ( 2017). Land useland cover changes and theirenvironmental implications in the Gelanasub-watershed of Northern highlandsof Ethiopia. Environmental Systems Research.

Mmbaga, E.N, L.K. Munishi, Treydte, Christina, \&Anna, (2017). How dynamics and drivers of land use/land cover change impact elephant conservation and agricultural livelihood development in Rombo, Tanzania. Journal of Land Use Science Volume 12.

MwesigyeF, T. Matsumoto \&K. Otsuka, (2017). Population pressure, rural-to-rural migration and evolution of landtenure institutions: The case of Uganda, Land Use Policy, Volume 65,

Nakalembe C, J. Dempewolf,\& C. Justice, (2017). Agricultural land use change in Karamoja Region, Uganda. Land Use Policy, Volume 62.

Pritchard\&F.Matthew, (2016). Contesting land rights in a post-conflict environment: Tenure reform and dispute resolution in the centre-West region of Côte d'Ivoire.Land Use Policy, Volume 54,

Rao,F., M. Spoor, X. Ma, Xiaoping, S. (2016). Landtenure (in)security and crop-tree intercropping in rural Xinjiang, China, Land Use Policy, Volume 50,

Ribeiro, S. C. L. Ramos, Isabel, L. Madeira, F. Barroso, H. Menezes, \& T.P Correia, Pinto, (2013), Is land cover an important asset for addressing the subjective landscape dimensions?. Land Use Policy. Volume $\underline{35}$. 
Ryder, S. S, \& P.M Hall, (2017). This land is your land, maybe: A historical institutionalist analysis for contextualizing split estate conflicts in U.S. unconventional oil and gas development.Land Use Policy, Volume 63.

Saputra, C. Aditya, (2015). Kelembagaan Sebagai Pondasi Penting Membentuk Karakter IndividuSelengkapnya. Student of Bogor Agricultural University.

Scott, C.J. (1983). Moral Ekonomi Petani. Jakarta: LP3S. Cetakan Kedua.

Si, J., F Nasiri; P. Han, \& Tianhong L. (2014).Variation in ecosystem service values in responseto land use changes in Zhifanggou watershed ofLoess plateau: a comparative study, Environmental Systems Research.

Spalding, A. K, (2017). Exploring the evolution of landtenure and land use change in Panama: Linking land policy with development outcomes. Land Use Policy, Volume 61,

Steven, A \& Baker, R. N, (2015). Ultraviolet photodegradation facilitates microbial litter decompositionin a Mediterranean climate. by the Ecological Society of America.

Sudrajat, (2013). Penguasaan Lahan Sawah Dan Keragaman Sumber Pendapatan Petani Di Pinggiran Kota Yogyakarta, Journal Patrawidya, Vol. 14, No. 4.

Suradisastra K,\& H. Kasim H. (1992). Analisis Agro-ekosistem Kabupaten Enrekang: AnalisisSistem Kecamatan Baraka dan Kasus Lahan Kering Desa Buttu Batu. KelompokPenelitian Agro-ekosistem. Badan Penelitian dan Pengembangan Pertanian danProyek Pengembangan Wilayah Sulawesi CIDA.

Susanti, A. , K. Hidayat\& Keppi S. (2013). Struktur Penguasaan Lahan Pertanian Dan Hubungan Kerja AgrarisPada Masyarakat Tengger(Kasus Di Dusun Krajan, Desa Sapikerep, Kawasan Pegunungan Tengger Lereng Atas), HABITAT Volume XXIV No. 1

Tjondronegoro, SMP \& Gunawan, W. (1984). Dua Abad Penguasaan tanah, Pola Penguasaan Tanah Pertanian di Jawa dari Masa ke Masa, Yayasan Obor Indonesia, Gramedia, Jakarta.

Tuyen, Q. N (2012). Land Holding Changes and Kinh and Khmer Farmers'Livelihoods in Thoi Thuan B Hamlet, Thoi Lai Town,Co Do District, Can Tho City, Vietnam. Asian Social Science, Vol. 8 No. 6

Uphoff, T.N, (1986). Local Institutional Development; An Alatical Sourcebook. WestHartford. Kumarian Press.

Winarso, B. (2012). Dinamika Pola Penguasaan Lahan Sawah di Wilayah Pedesaan diIndonesia, Jurnal Penelitian Pertanian Terapan Vol. 12 (3): 137-149ISSN 1410-5020.

Yunus, A., D. Salman, E.B. Demmallino,\& N.M. Viantika, (2016). Sociotechnical Change and Institutional Adjustment in Paddy Rice Farming During Post Green Revolution in Indonesia. International Journal of Agriculture System, Vol. 4, No. 2.

Zheng, Q, \& Ran, R.(2012).. Study on Driving Forces in Quantity, Changes of Cultivated Land inYubei District, Chongqing, China . Asian Social Science Vol. 8, No. 6. 
